\title{
New insights into the pathogenesis of cardiac papillary fibroelastomas
}

\author{
Natalia Matysiak $^{1 \oplus, \text { Lukasz Mielanczyk }^{1, *} \odot \text {, Krzysztof Kaczmarek }}{ }^{2}$, \\ Malgorzata Zaba $^{1}$, Edyta Reichman-Warmusz ${ }^{1 \oplus}$, Romuald Wojnicz ${ }^{1} \odot$
}

\author{
${ }^{1}$ Department of Histology and Cell Pathology, FMS in Zabrze, Medical University of Silesia, \\ Katowice, Poland \\ ${ }^{2}$ Department of Electrocardiology, Medical University of Lodz, Lodz, Poland
}

\begin{abstract}
Introduction. Cardiac papillary fibroelastomas (CPFs) are rare benign cardiac tumors typically found on the heart valves. The previously published data on the CPF focused on its clinical presentation, optimal management, and prognosis. However, histogenesis of these lesions remains controversial. Accordingly, the aim of this study was to establish the role of endocardial endothelium (EE) in CPF formation.

Materials and methods. Four CPF tumors removed from the right atrioventricular valves were analyzed using hematoxylin \& eosin, orcein, and Masson trichrome staining together with immunochemistry for CD-34, CD-68, vimentin, $\mathrm{vWF}$ and $\alpha$-SMA. Moreover, conventional transmission electron microscopy was used for morphological analysis and $\alpha$-SMA presence confirmation.

Results. Ultrastructural morphology, immunohisto- and immunocytochemical analyses indicated that cells covering collagenous core have an endothelial origin. Some endocardial endothelium cells have the potential to undergo a transition to mesenchymal cells. Moreover, the abundant presence of extracellular vesicles may indicate an active intercellular communication. Within the intermediate translucent zone, amorphous substances with monocytes/macrophage-like cells and fibroblastic cells were found. Finally, within collagenous core activated (myo)fibroblasts were observed.

Conclusions. Our study demonstrated that the endocardial endothelium of the CPF was "double-sided", i.e., it presented both endothelial and mesenchymal cell characteristics. Another finding was the presence of monocytes, and macrophages which were integrated into CPF core and displayed features of a fibroblast that have been shown to contribute to extracellular matrix production. This could be interpreted as being attributed to the CPF histogenesis. (Folia Histochemica et Cytobiologica 2021, Vol. 59, No. 4, 212-225)
\end{abstract}

Key words: cardiac papillary fibroelastoma; endocardial endothelium; endothelial to mesenchymal transition; EMT; ectosomes; myofibroblast; cardiac benign tumors; electron microscopy

\section{Introduction}

Cardiac papillary fibroelastomas are rare benign cardiac tumors with poorly understood etiology. The lesions usually occur on the surface of valve

Correspondence address: Lukasz Mielanczyk, MSc

Department of Histology and Cell Pathology

Medical University of Silesia in Katowice, Poland

Jordana St. 19, 41-808 Zabrze

e-mail:1mielanczyk@sum.edu.pl leaflets [1-7]. It is still debated whether these lesions represent a regenerative or reactive process of the endocardium. Considering its valvular localizations, it was suggested that the CPF arise as a response to hemodynamic stress or valve injury [8-10]. Histologically, CPFs are lesions covered by a single layer of endocardial endothelium. Matrix (fibrous cores) is composed of proteoglycans, elastic fibers, and randomly distributed single fibroblasts and other cells of mesenchymal origin $[1,11]$.

This article is available in open access under Creative Common Attribution-Non-Commercial-No Derivatives 4.0 International (CC BY-NC-ND 4.0) license, allowing to download articles and share them with others as long as they credit the authors and the publisher, but without permission to change them in any way or use them commercially. (C) Polish Society for Histochemistry and Cytochemistry 
Growing evidence suggests that endothelial to mesenchymal transition (EndoMT) is closely related to the pathogenesis of cardiovascular disease, including valvular disease, cardiac fibrosis, and fibroelastosis [12-16]. It can be observed that during EndoMT, endothelial cells lose some of their morphological features such as flat and elongated shape, tight adherence to the basement membrane, characteristic nuclei orientation, and presence of tight junctions [17-19]. On the other hand, endothelial cells gain particular phenotype characteristics, including e.g. hypertrophic changes, formation of cellular protrusions as well as increased secretion of extracellular matrix proteins $[11,12,20,21]$.

The majority of previous data on CPF focused on its clinical course and treatment modalities. Only a few reports tried to explain the histogenesis of these lesions [8]. Thus, the aim of this study was the subcellular analysis of CPF using electron microscopy and immunocytochemical methods to provide a hypothesis for the genesis of these tumors. With the above considerations in mind, the current investigation was undertaken to determine the active participation of $\mathrm{EE}$ in the CPF formation.

\section{Material and methods}

We studied four cases of cardiac papillary fibroelastoma obtained from four females, aged 72-80 years. CPF in all patients was discovered incidentally by echocardiography. Two patients were admitted to the hospital due to frequent episodes of mild dyspnea and transient neurological defects, the third due to myocardial ischemia, and the fourth due to symptomatic complete atrioventricular block. All lesions were percutaneously removed from the tricuspid valve by a new approach known as the "snare over cryocatheter" technique [22]. The removed frozen masses were divided and fixed separately for histochemistry, immunohistochemistry, and electron microscopy. Human subjects provided us with an oral assurance of their willingness to participate in research studies on human tissues was approved by the Research Ethics Committee of using procedures that conformed to the guidelines of the Declaration of Helsinki.

For histochemistry, tissue sections were fixed in $10 \%$ buffered formalin and embedded in paraffin. For histological examination, paraffin sections ( $5 \mu \mathrm{m}$ thick) were routinely stained with hematoxylin and eosin (HE), orcein, and Masson trichrome.

Immunohistochemistry. Small tissue specimens were fixed for $30 \mathrm{~min}$ in cold acetone, immersed in embedding medium (OCT compound, Miles Inc, Elkhart, IN, USA), and cut serially into $5 \mu \mathrm{m}$-thick sections on a Shandon Cryotome FSE (Thermo Fisher, Leicester, UK). Frozen sections were incubated with murine monoclonal antihuman antibodies: ant-CD68 (clone KP1, Thermo Scientific, San Diego, CA, USA), anti-CD34 (clone EP373Y Abcam, Cambridge, UK), anti-vimentin (clone Vim 3B4, DAKO, Glostrup, Denmark), and anti- $\alpha$-SMA (alpha-smooth muscle actin) antibodies (polyclonal Gene Tex, Hsinchu City, Taiwan). For visualization, the EnVision method (DAKO EnVision $\mathrm{Kit}^{\circledast} /$ Alkaline Phosphatase detection system) was used according to the manufacturer's instructions. The primary antibody was omitted from negative control slides. As the positive control, liver biopsy specimens from patients with chronic active hepatitis were used. To suppress nonspecific staining due to endogenous alkaline phosphatase activity, Levamisole was used at a final concentration of $0.2 \mathrm{mM}$. The sections were counterstained with Mayer's hematoxylin.

Transmission electron microscopy and immunoelectron microscopy. Tissue specimens were fixed in $2.5 \%$ glutaraldehyde in a cacodylate buffer ( $\mathrm{pH}$ 7.4) for $2 \mathrm{~h}$, post-fixed in $1 \% \mathrm{OsO}_{4}$, and dehydrated in an increasing concentration of ethanol and propylene oxide series. Subsequently, the specimens were infiltrated in 2:1 (v:v) and 1:2(v:v) propylene oxide/Epon 812 mixture, embedded in Epon 812 epoxide resin and polymerized for $48 \mathrm{~h}$ at $60^{\circ} \mathrm{C}$. Semithin sections were stained with toluidine blue $(1 \%)$ and examined by light microscopy. The ultrasections ( $70 \mathrm{~nm}$ thick) were mounted on 200 mesh copper grids and stained with $0.5 \%$ aqueous uranyl acetate and lead citrate using Leica EM AC20 Stainer (Leica, Vienna, Austria).

For immunoelectron microscopy, specimens were fixed in $4 \%$ paraformaldehyde in $0.1 \mathrm{M}$ phosphate-buffered saline (PBS), $\mathrm{pH} 7.4$ for $2 \mathrm{~h}$ at room temperature, and washed several times in PBS. After washing, the tissue pieces were dehydrated in graded ethanol series and infiltrated in 2:1 (v:v) and 1:2 (v:v) ethanol/LR White mixture, 30 min each on ice. Then the samples were infiltrated in pure LR White. After $2 \mathrm{~h}$ the resin was exchanged and allowed to stand overnight at $4^{\circ} \mathrm{C}$. The resin was exchanged again the next day, and after $2 \mathrm{~h}$ the samples were placed into gelatin capsules and polymerized for $48 \mathrm{~h}$ at $55^{\circ} \mathrm{C}$. Ultrathin sections $(70$ $\mathrm{nm}$ ) were cut using ultramicrotome Power Tomo PC RMC Boeckeler equipped with a diamond knife $\left(45^{\circ}\right.$; Diatom AG, Biel, Switzerland). Ultrasections were mounted on Formvar-coated 200 mesh nickel grids and immunolabelled. The sections on grids were first pre-incubated for $30 \mathrm{~min}$ by floating on drops of $50 \mathrm{mM} \mathrm{NH}_{4} \mathrm{Cl}$ in PBS, subsequently blocked for $30 \mathrm{~min}$ on drops of $1 \%$ BSA in PBS. This was followed by incubation overnight $(16-18 \mathrm{~h})$ at $4^{\circ} \mathrm{C}$ with primary anti- $\alpha$-SMA antibody diluted 1:50 in BSA. Then the grids were washed on drops of PBS (five changes, $3 \mathrm{~min}$ each) and bound antibodies were localized by incubating the sections for $1 \mathrm{~h}$ on Immunogold conjugated goat anti-mouse IgG 15 nm (BBInternational BBI Solutions, Sittingbourne, UK) diluted 1: 100. Finally, grids were washed on drops of 
PBS (five changes, 5 min each) and water (three changes, 3 min each) before being stained with $0.5 \%$ aqueous uranyl acetate. In controls, the primary antibody was omitted. All incubations, except for the primary antibody step, were carried out at room temperature. Subsequently, the grids were air-dried and examined under TECNAI 12 G2 Spirit Bio Twin FEI Company transmission electron microscope at $120 \mathrm{kV}$. Images were captured with a Morada CCD camera.

\section{Results}

All cases presented typical histological features of CPF with bundles of papillary projections with a collagenous core surrounded by a single layer of EE (Figs. 1 and 2). These cells presented positive staining for CD34 and von Willebrand Factor (vWF) on cryostat sections by immunohistochemistry indicating its endothelial origin (Fig. 3). Electron microscopy revealed that some of them were either multinucleated (Fig. 7C) or had segmented fragments of nucleus lined by the discontinuous basement membrane (Fig. 4A). The remaining ultrastructural features of EEC (endocardial endothelial cells) covering CPFs were as follows: (1) cuboidal shape, (2) numerous microvilli on the luminal surface, (3) well-developed endoplasmic reticulum, (4) heterogeneous population of extracellular vesicles (EVs) (Fig. 5). All these changes account, at least in part, for the cellular activation.

The EVs can assume two forms. The first one is characterized by clusters of endomembrane vesicles gathered and budded from the endothelial plasma membrane (extracellular multivesicular bodies) and the second one is manifested by many clusters of microvesicles (exosomes and ectosomes).

Some of the EECs were positively stained by anti- $\alpha$-SMA and anti-vimentin antibodies by immunohisto- and immunocytochemistry suggesting their ability for transdifferentiating into mesenchymal cells (Fig. 6). This assumption was further supported by an ultrastructural study indicating their migratory phenotype. These transitional cells presented a discontinuous basement membrane, cell-to-cell junction rearrangements (loss of cell-to-cell contacts), and marked cytoskeleton reorganization (Fig. 7, Fig. 11). A few of these EECs were penetrated into the intermediate zone, also known as subendothelial space, and their endothelial origin may be confirmed by the presence of caveolae at their surface (Fig. 8). Moreover, the intermediate translucent zone was occupied by an amorphous ground substance and a few collagen fibers. Occasionally, as demonstrated by immunohistochemistry and electron microscopy, peripheral blood mononuclear cells, monocytes macrophage-like cells, and fibroblastic cells were also observed. CD68 positive cells were localized on the superficial endothelial layer and in the subendothelial space of tumors (Fig. 9 (CD68)). Moreover, the ultrastructural analysis showed that macrophage-like cells were loosely scattered in subendothelial space or adhered to the collagen fibers. Cells at the matrix surface changed shape from round to fusiform, partially reduced surface protrusions and gradually incorporated into fibrocollagenous matrix (Fig. 9).

As far as the CPF core is concerned, the majority of cells in the core had the ultrastructural features of activated fibroblasts or myofibroblasts such as abundant, dilated rough endoplasmic reticulum, well-developed contractile apparatus with sub-plasmalemmal attachment plaques maintain cell to matrix adhesion (focal adhesion) and positive $\alpha$-SMA staining (Fig. 10).

\section{Discussion}

The present study demonstrated that endocardial endothelial cells might actively participate in the formation of CPFs as indicated by their histological, immunohistological and ultrastructural features, including e.g., the degradation of the endothelial basement membrane, cell-to-cell junction rearrangements, cytoskeleton reorganization, and focal $\alpha$-SMA and vimentin positivity. The ultrastructural alterations reveled by TEM appear to be related to a mesenchymal phenotype of endocardial endothelial cells and may indicate initiation of transdifferentiation into mesenchymal cells. Our results are in line with studies showing changes in human valvular endothelial cells phenotype cultured in a 3D hydrogel and exposed to chronic high glucose conditions. Ultrastructural analysis performed by Cecoltan et al. showed an increased abundance of intermediate filaments and attenuation of intercellular junctions. Besides ultrastructural results, higher expression of mesenchymal markers, such as vimentin and $\alpha$-SMA, indicated on the participation of high glucose conditions in EndMT process via VEC inflammation [23]. In addition, secretion of extracellular vesicles by endocardial endothelial cells into the extracellular space may be, in part, attributable to the remote regulatory function of these cells.

It is well established that EVs are key players in cell-to-cell communication both under physiological and pathological conditions [24-27]. Extracellular vesicles are capable of transferring biological information because they contain a diverse cargo of lipids, proteins, mRNAs, miRNAs, DNA fragments, and metabolites, which can modulate biological functions in target cells $[28,29]$. Under physiological conditions, endothelial cells secrete EVs into the blood in low concentrations. However, EVs levels have been 

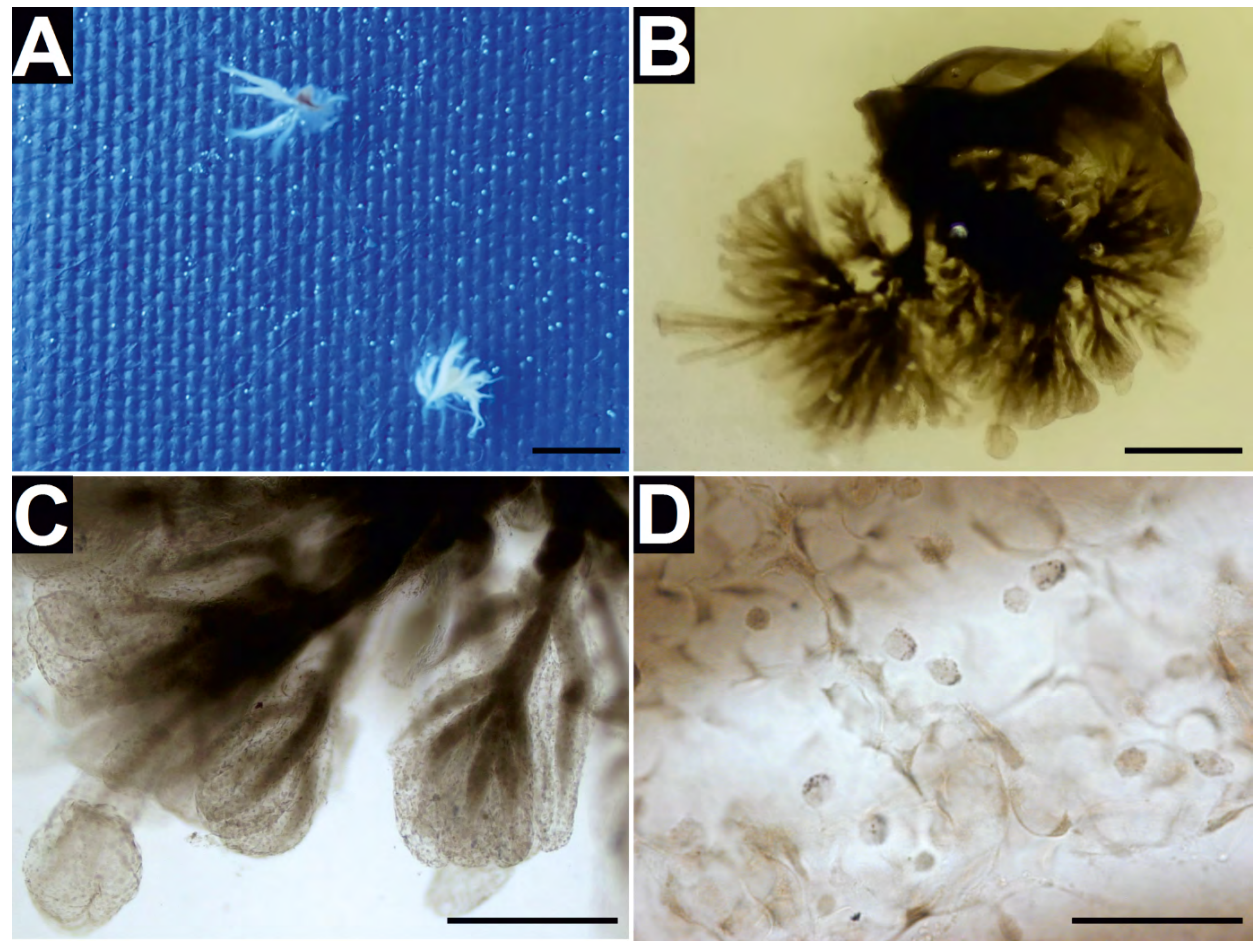

Figure 1. Macroscopic appearance of fibroelastoma tumors. A. Representative images of gross view of the resected tumors which resembled a sea anemone when immersed in fixative liquid. B. The specimen after osmification and epoxy resin infiltration. C. Microscopic aspect of the tumor: after epoxy resin infiltration, the specimen was placed on a microscopic slide and observed under a light microscope. Photomicrograph shows multiple projections with swollen tops, covered by endothelial cells and containing dense cores, some of the papillae have a „drummer's baton” shape. D. Higher magnification confirmed surface-covering flat cells and revealed the presence of cells with dark granules in cytoplasm. Magnifications: C, 40×; D, 400×.

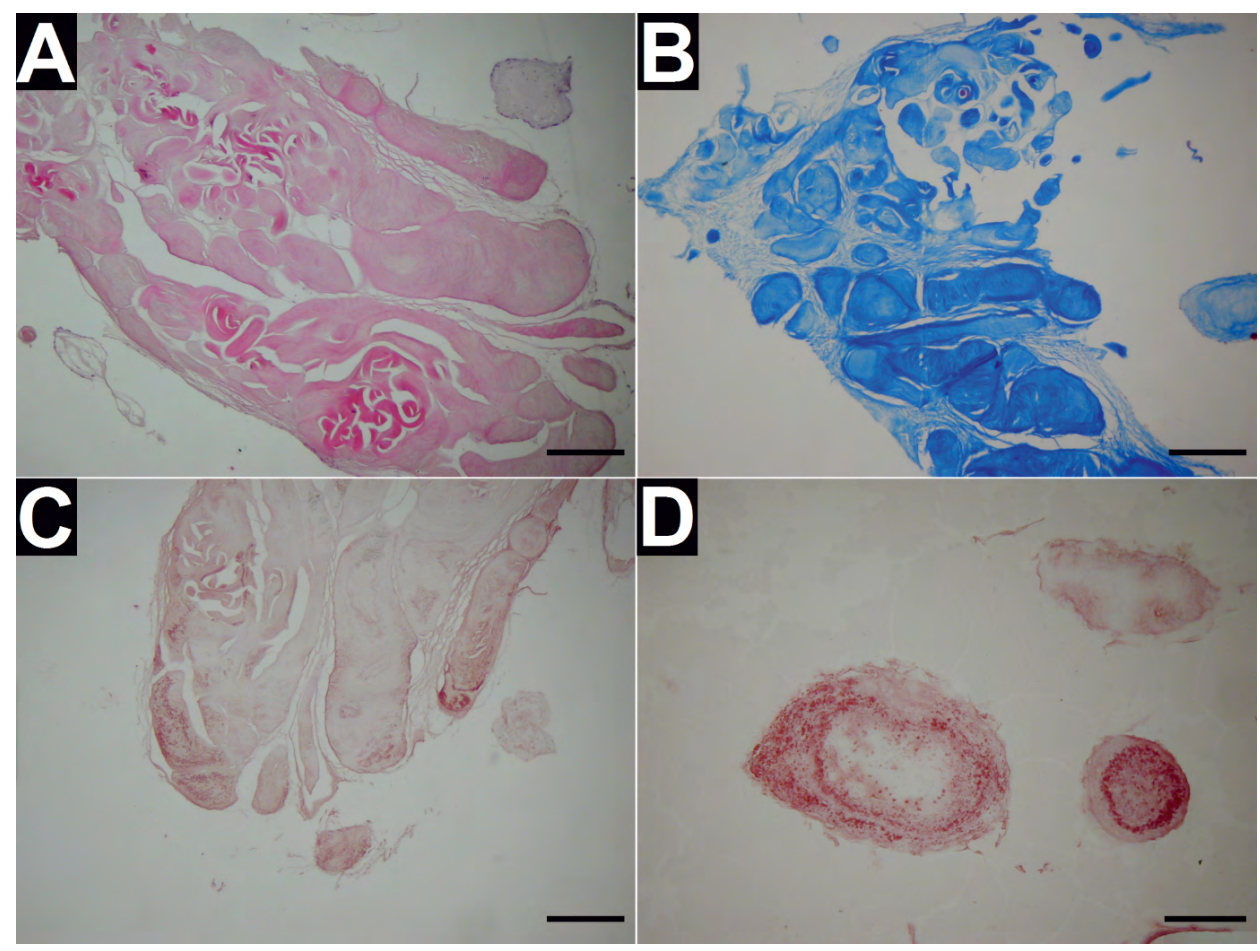

Figure 2. Various staining methods reveal the histological structure of fibroelastoma tumor. A. Multiple avascular papillary fronds are composed of collagenous tissue and are lined by the endothelial cells (H\&E staining). B. Masson trichrome staining of the tumor revealed characteristic dense core collagen branches. C, D. Orcein staining of papillary fronds showing the fibroelastic cores. Magnifications: A, 40×; B, 40×; C, 40×; D, 100×. 


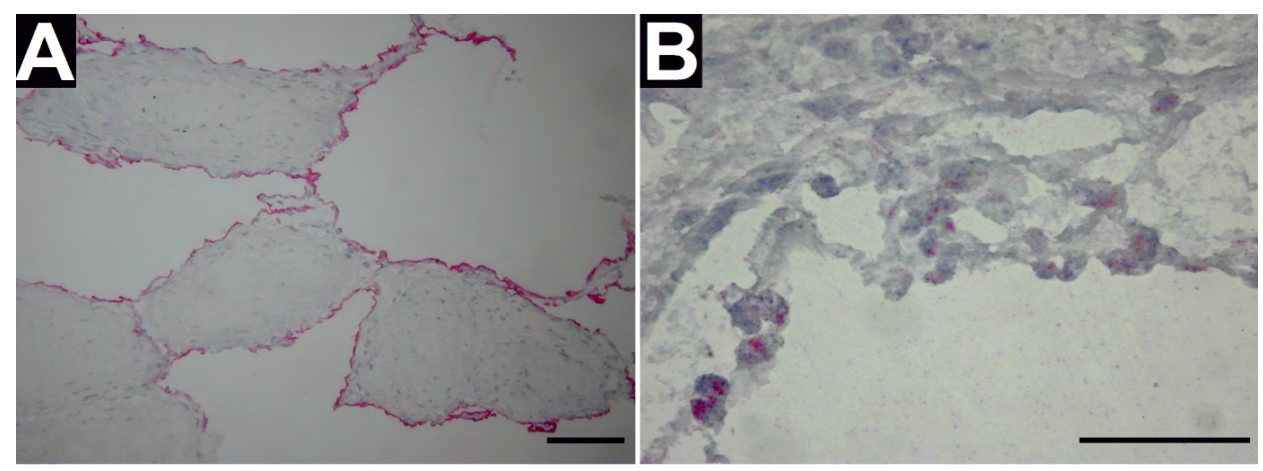

Figure 3. Immunohistochemical staining of endothelial cells in papillary fibroelastoma. A. CD34 and B. vWF markers are positive on surface lining endocardial endothelial cells, visible as red staining. Magnifications: A, 100×; B, 400×.

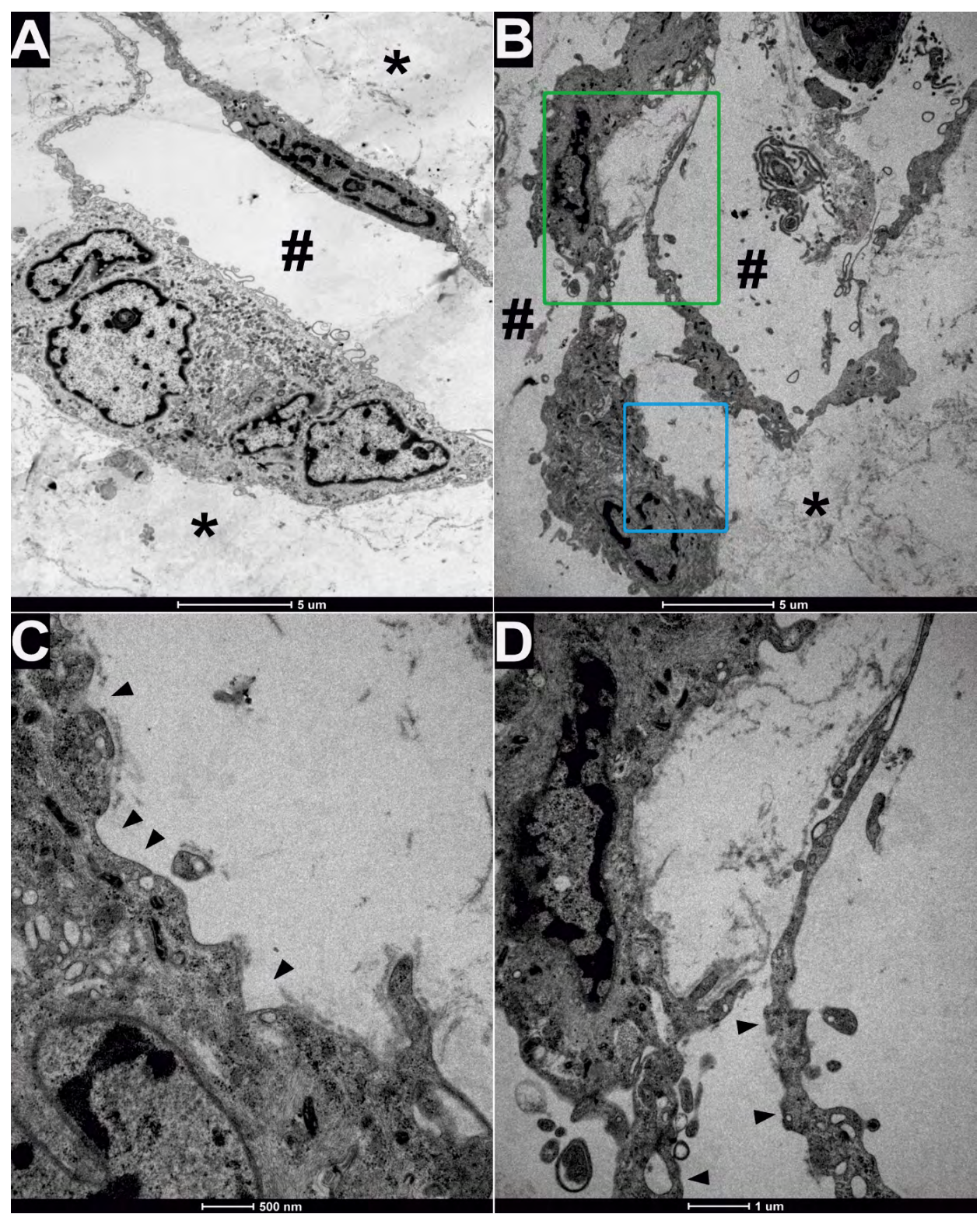

Figure 4. Transmission electron microscopy (TEM) images of endothelial endocardial cells in fragments of cardiac papillary fibroelastoma (CPF) segmentes lining an amorphous ground substance (asterisks), A, B. Enlarged blue and green insets of the image $B$ are shown at $C$ and $D$, respectively. The cells have irregularly shaped nuclei with peripherally arranged heterochromatin, the cytoplasm is rich in organelles. Micrographs showing discontinuous (arrowheads) basement membrane, small cytoplasmic processes are visible on the apical surface of the endothelial cells. \# indicates external space outside of the CPF. 


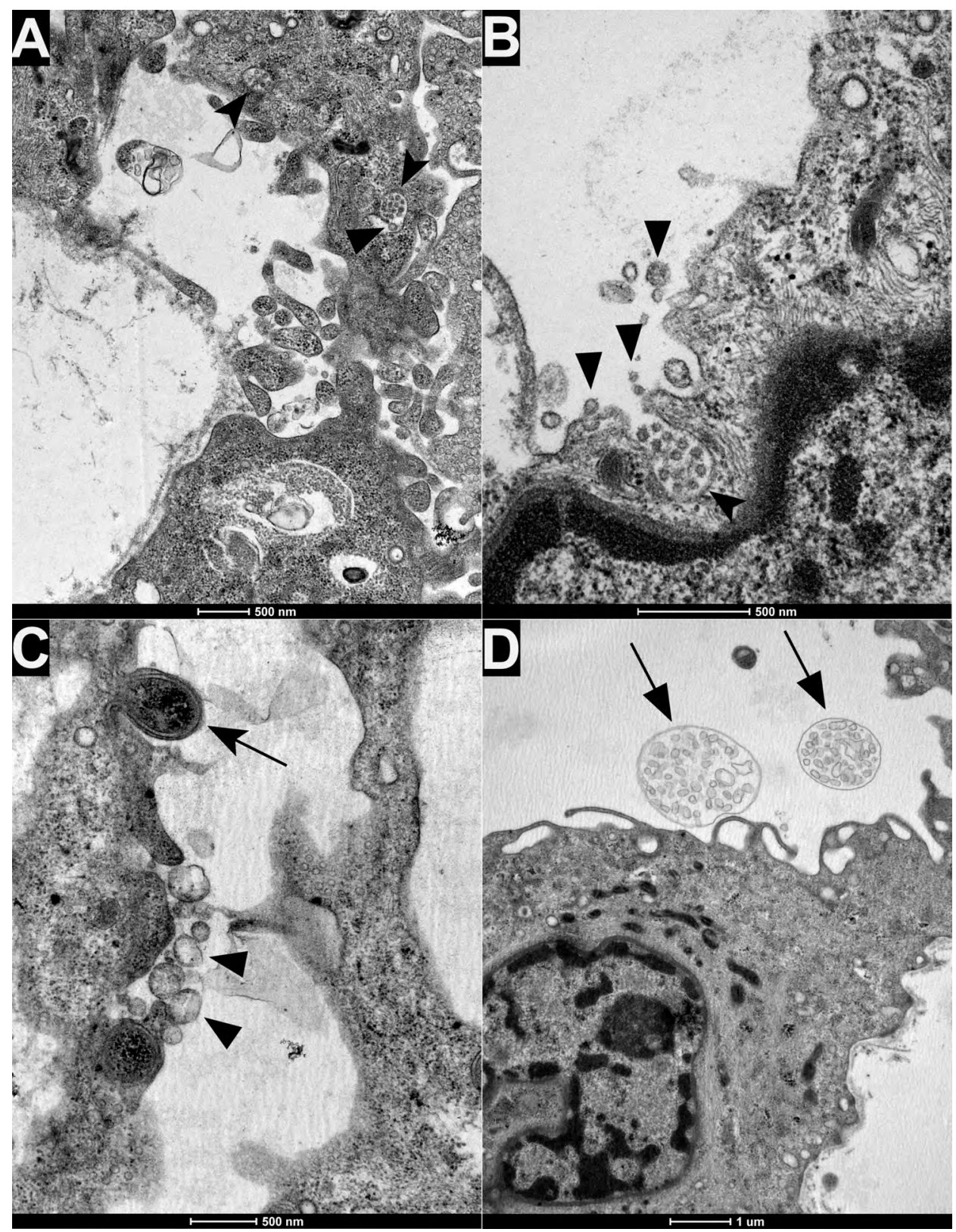

Figure 5. TEM images of extracellular vesicles released by activated endocardial endothelial cells (EECs) present in papillary fibroelastoma. A. Multivesicular bodies are visible in the cytoplasm of endothelial cells (notched arrowhead). B. Exosomes as intraluminal extracellular vesicles filled with multivesicular bodies and released into extracellular space (notched arrowhead). Note the numerous small vesicles close to the plasma membrane (filled arrowhead); C. Ectosome (notched arrow) released from the plasma membrane of the EEC. D. Multivesicular cargo in form of clusters of endomembrane vesicles surround by the plasma membrane in ectosomes released into extracellular milieu (arrows).

shown to increase in cardiovascular diseases involving endothelial injury or dysfunction [30-33]. Currently, little is known about the physiological role of EVs derived from EC, however, the latest reviews suggest that EVs may be involved in the maintenance of endothelial homeostasis $[29,34]$ and fetal development [29]. As mentioned above, EVs have been implicated in the induction of EndoMT in various pathological conditions, for example: melanoma-derived EVs in- duced EndoMT in Human umbilical vein endothelial cells (HUVECs) in vitro [35], adipose microvascular endothelial cells undergo in vitro EndoMT when exposed to EVs obtained from adipose tissue of patients with obesity [29]. Moreover, EC that displayed mesenchymal characteristics in response to pro-inflammatory cytokines, released larger numbers of EVs compared with control EC [36]. Furthermore, recent studies suggest that endothelium-derived extracellular 


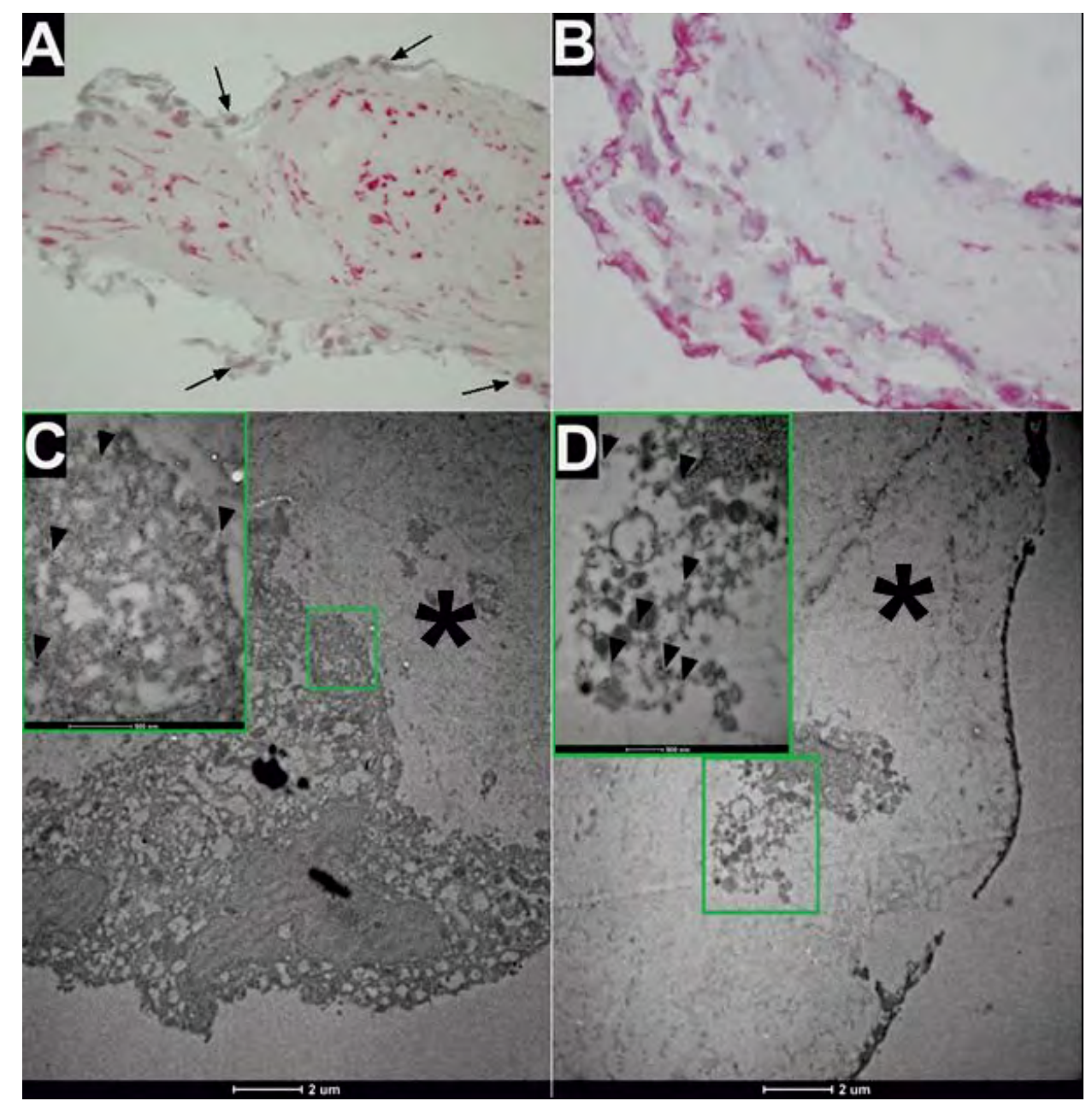

Figure 6. Immunohistochemistry of the cardiac papillary fibroelastoma (CPF). A. A few endocardial endothelial cells (EEC) are moderately immunopositive for $\alpha$-SMA (red staining, thin arrow). Enhanced $\alpha$-SMA expression is visible in numerous cells located in the core of papillae. B. Vimentin immunoreactive cells (red) are present in the papillae. C. Immunogold labeling of $\alpha$-SMA in CPF: only a few EEC exhibited gold particles in the invagination directed toward the loose myxoid tissue (marked with an asterisk) of the papillary frond. In the insert, the gold particles were visible near the plasma membrane and in the cytoplasm (arrowheads). D. Moreover, gold particles are presented not only in EECs, but also in the cells embedded in fibrocollagenous cores. Magnifications: A, $150 \times$; B, $400 \times$.

vesicles promote splenic monocyte mobilization after myocardial infarction both in mice and humans [37]. Our ultrastructural analysis showed a numerous and heterogeneous population of extracellular vesicles shedding by endocardial endothelium, as a result of activation rather than apoptosis. We report the presence of vesicles, their size, and morphology, however, electron microscopy is not suitable for quantifying EVs [33].

Additionally, extensive research over the last decades has indicated that the repeated stress to the endocardial/endothelial cells has been suggested as a cause of the alterations of the cell morphology. Changes in the shape of the cell with elongation, hypertrophy, and alignment of the cells and their stress fibers were observed in primary atrial endocardial en- dothelial cells in vitro subjected to mechanical stretch. Authors showed that after $4 \mathrm{~h}$ of stretch, the cells exhibited significant downregulation of the EEC specific cell-adhesion proteins VE cadherin and PECAM-1 which is suggestive of changed EEC permeability [38]. Dal Bianco et al. demonstrated that, mechanical stresses imposed by papillary muscle tethering increase MV leaflet area and thickness, with cellular changes. In stretched leaflets showed both CD31 and $\alpha$-SMA staining in the endothelial layer, suggesting reactivated embryonic developmental pathways known as endothelial to mesenchymal transition [39]. Our results are consistent with those from the recent studies demonstrating that some valvular endothelial cells have the potential to undergo a transition to mesenchymal cells. This highly dynamic process in which 


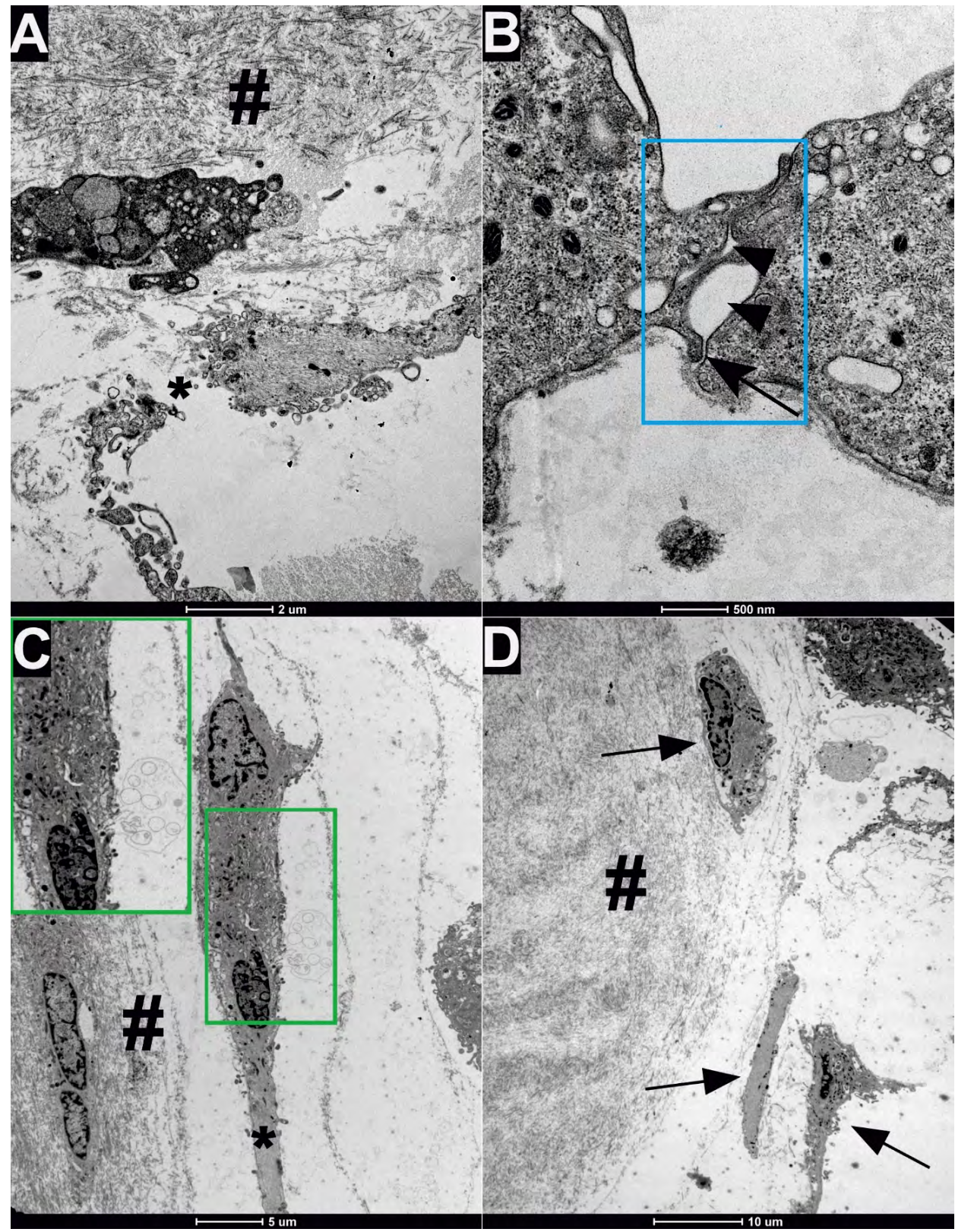

Figure 7. Overview of EM micrographs reveals loss in the continuity of the superficial endothelial layer in cardiac papillary fibroelastoma (CPF). A. The gaps are present between surface lining endocardial endothelial cells (EECs) (asterisk). B. Presence of cell-to-cell junction rearrangements in a form of overlap between junctional areas in EECs, extended intercellular clefts (arrowheads), and single interrupted tight junctions (notched arrow). TEM analysis showed that EEC is connected by loose intercellular contacts with intermembrane distance (blue rectangle). C. Subendothelial space is filled with ground substance, loosely packed collagen fibers, and transitional cells displaying a mixed phenotype. A double-nucleated transitional cell exhibited well-developed endoplasmic reticulum (green rectangle), numerous vesicles, and aggregation of intermediate filaments in the cytoplasm (asterisk), see Fig. 11. D. Another area of CPF tumor's papilla shows a few cells (arrows) or their cytoplasmic processes exhibiting typical features of transitional cells. \# indicates CPF's fibrocollagenous core.

EECs lose their endothelial phenotypes, acquire mesenchymal or myofibroblastic properties, and express mesenchymal cell markers such as $\alpha$-SMA, vimentin, fibronectin, and fibroblast-specific protein $1[40,41]$.

The process of the endocardial endothelium transition has an important role in the endocardial cushion formation during heart valve development [20, 42-44]. In addition, recent reports indicated that endothelial-to-mesenchymal transition may also occur in postnatal valves in response to injury and contributes to the development of various cardiovascular diseases, including myocardial infarction, cardiac 


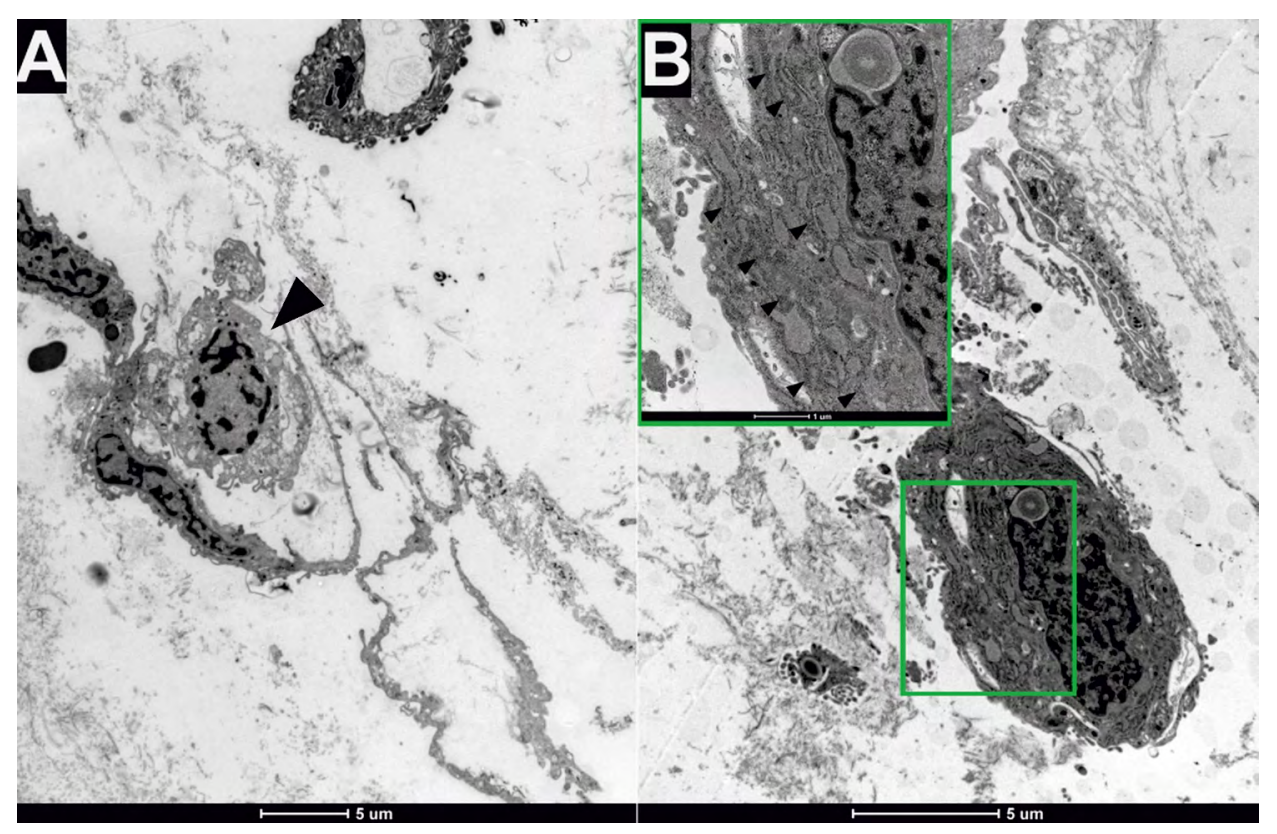

Figure 8. TEM micrographs of subendothelial cells in cardiac papillary fibroelastoma (CPF). A. Activated fibroblast-like cells (arrowhead) are visible in the subendothelial area, the cell has an irregular outline due to the presence of cytoplasmic protrusions. Another endocardial endothelial cell is visible in the upper part. B. Note the presence of prominent rough endoplasmic reticulum with dilated cisterns and abundance of free ribosomes and polyribosomes in the cytoplasm (arrowheads).

fibrosis, valve calcification, endocardial elastofibrosis, atherosclerosis, and pulmonary arterial hypertension $[12,23,41,45]$.

Using transmission electron microscopy and immunohistochemistry we demonstrated the migratory phenotype of ECs which have the potential to undergo a transition to mesenchymal cells with a gain of $\alpha$-SMA and vimentin markers, the loss of basement membrane continuity, and cell-to-cell contacts. Moreover, we have shown that EC is presumably the source for $\alpha$-SMA positive cells that occur in fibrocollagenous core. To the best of our knowledge, there is no data on the endothelial cells' participation in CPF development. However, our results are in line with the research providing in situ evidence of EndoMT in human and experimental pulmonary hypertension $[17,19]$.

The mechanism underlying the transition of EE to mesenchymal cells is still incompletely understood. Endothelial-to-mesenchymal transition can be induced by various biochemical and biomechanical triggers in the endothelial cells microenvironment. Transforming growth factor beta TGF $\beta$, is the most extensively studied mediator causing endothelial cells to undergo EndoMT. In in vitro experiments investigating the impact of inflammation on EndoMT, TGF $\beta$ is used alone as stimulus or in combination with tumor necrosis factor- $\alpha(\mathrm{TNF} \alpha)$ and interleukin- $1 \beta$
(IL-1 $\beta)[46,47]$. A few reports have shown that endothelial-to-mesenchymal transition is induced by mechanical forces (activators) such as flow and shear stress, matrix composition and stiffness, stretch and cyclic strain [47, 48]. Accordingly, endothelial cells' responses to EndoMT triggers are heterogeneous and are dependent on different factors for example mechanical activators of EndoMT cause mechanical hallmarks such as endothelial monolayer disruption and invasion into the extracellular matrix [47]. In the experimental study by Dal- Bianco et al., mechanical stress imposed by papillary muscle tethering led to the increase in the valve area and its thickness. In this model, EE cells co-expressed CD31+ and $\alpha$-SMA in leaflets of stressed hearts [39, 41]. As revealed by another study, co-expression of CD $31+$ and $\alpha$-SMA in valvular endothelial cells was indicative of active endothelial-to-mesenchymal transition process [42, 49-51].

Based on our study and the review of the literature, we are of the opinion that activated EE participates in the development of CPF by means of focal endothelial-to-mesenchymal transition and the recruitment of monocytes that migrate from the blood through the endothelial barrier to the area of potential damage and undergo a transition into macrophages and finally into myeloid fibroblasts or myofibroblast. This process can be modulated by endothelial and stromal cells such as fibroblasts and macrophages and attribut- 


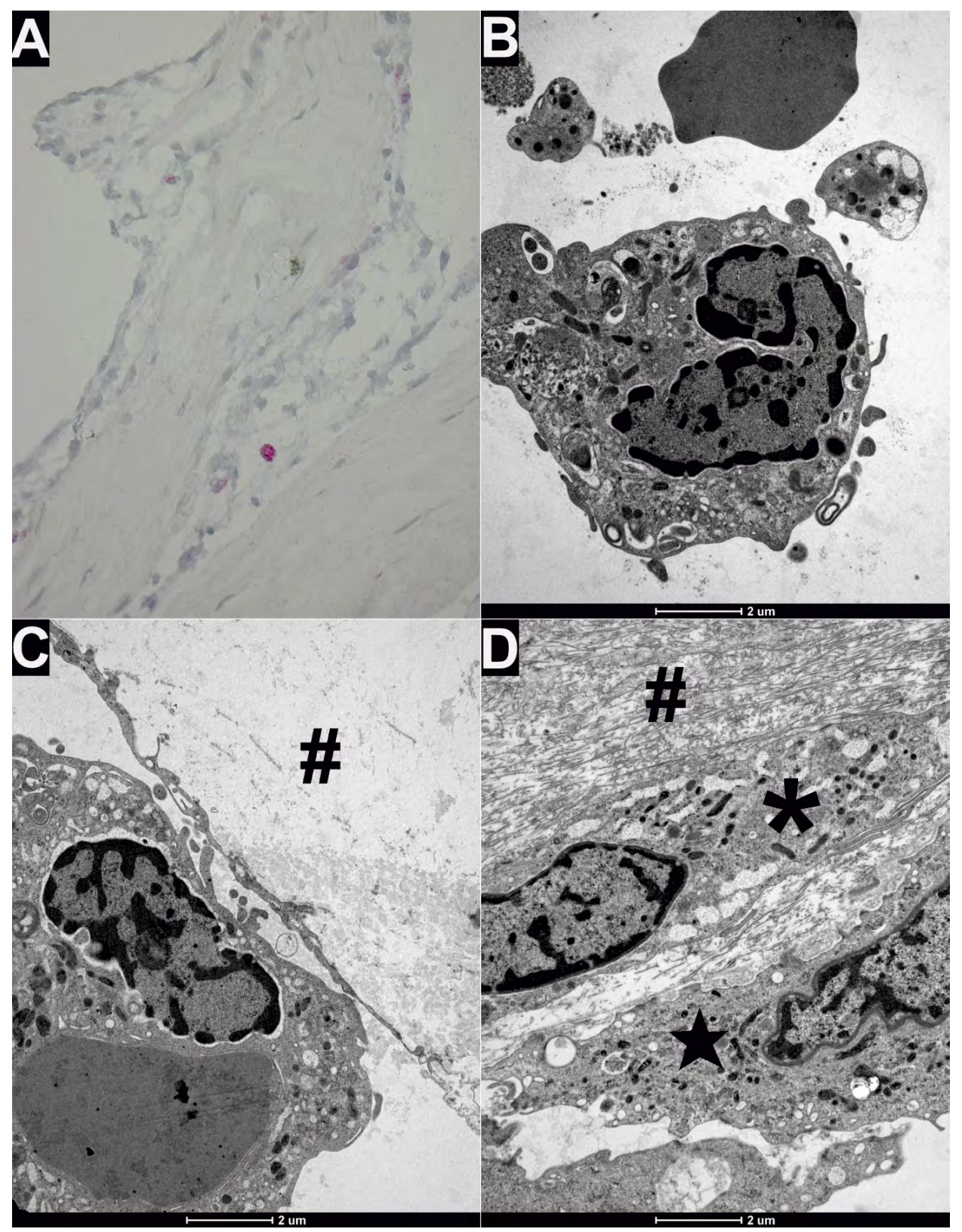

Figure 9. TEM micrographs show part of cardiac papillary fibroelastoma (CPF). A. Macrophages (red) are detected as CD68-immunoreactive single cells. The labelled cells were localized both in the close proximity to endothelial cells lining and in subendothelial space. B. Mononucleated, rounded cells with cell membranes characterized by dendritic filopodia are visible in a subendothelial zone. These cells demonstrate typical features of macrophages, i.e. irregular cell outline with protrusions, numerous phagocytic vacuoles in cytoplasm, irregularly-shaped nucleus. The structure in the upper part is deformed erythrocyte. C. Macrophage with phagocytosed erythrocyte. D. Fragment of fibrocollagenous core of CPF surrounded by activated endocardial endothelial cells (star). Note the fibroblast-like cell (asterisk) embedded in collagen fibers under the endothelial layer. This cell contains numerous mitochondria and distinct endoplasmic reticulum with dilated cisterns. \#indicates subendothelial space (C) and fibrocollagenous core (D). Magnification: A, 200×.

ed to elevated levels of monocyte chemoattractant protein-1 [52-56]. Other studies reported that bone marrow-derived macrophages can transdifferentiate into collagen-producing $\alpha \mathrm{SMA}^{+}$myofibroblasts via TGF- $\beta /$ Smad3 signaling through macrophage to myofibroblast transition during renal fibrosis [57-59].
Additionally, Haider et al. used myeloid specific cre reporter mice LysM $\left(\mathrm{Cre}^{/+} ; \mathrm{ROSA}_{26}\left(\mathrm{EYFP}^{/+}\right)\right)$ demonstrated that macrophages can transdifferentiate into fibroblast-like cells in the post-myocardial infarction heart [60]. The papillary projections subsequently expanded with accumulating extracellular 


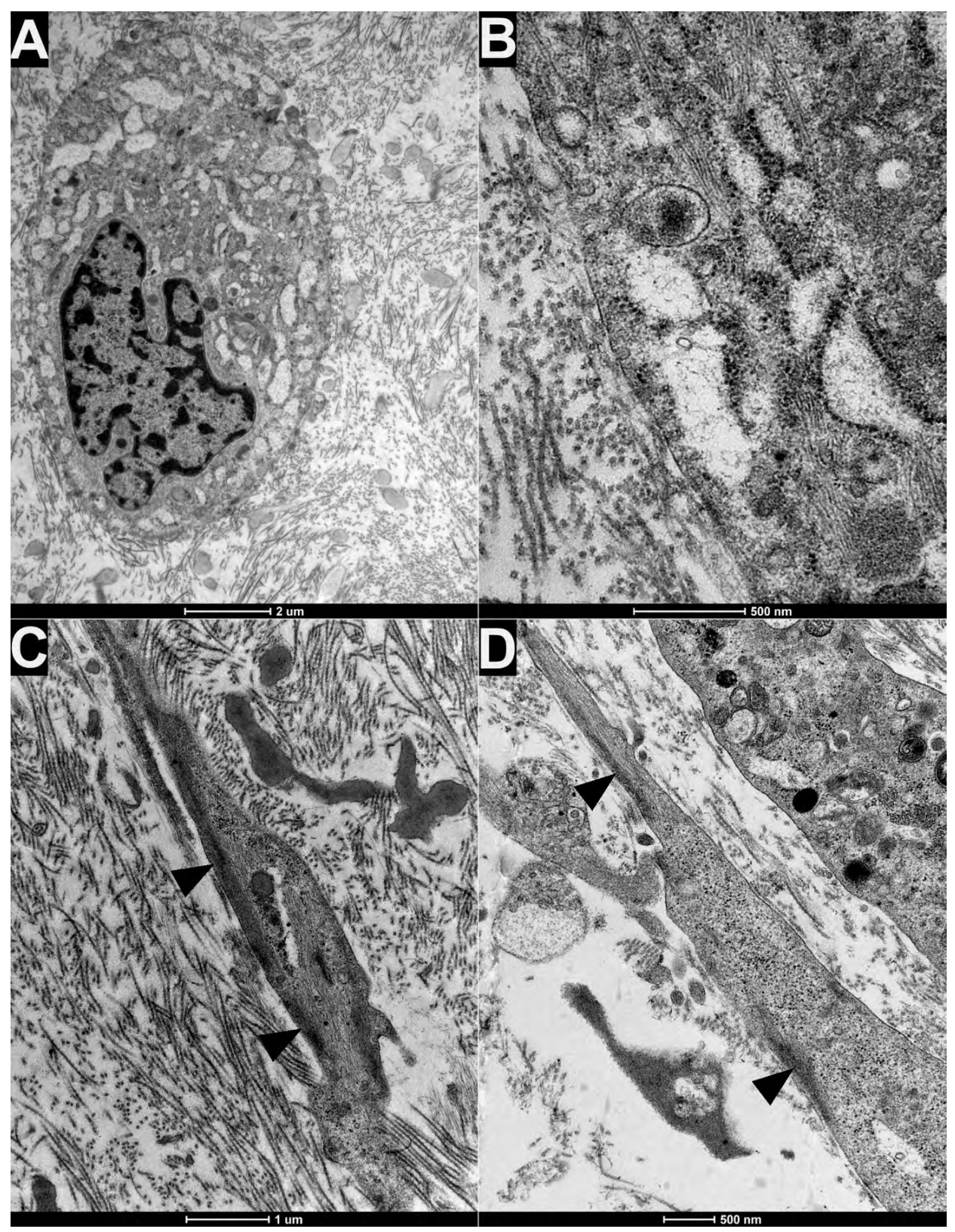

Figure 10. Ultrastructure of central core of cardiac papillary fibroelastoma (CPF) papillae. TEM micrographs display fibroblasts (A and B) and myofibroblast (C and D) embedded in collagenous and elastic matrix: A, B. Activated fibroblasts with well-developed endoplasmic reticulum which cisternae are expanded. C, D. Myofibroblasts can be identified by sub-plasmalemmal microfilament bundles or sub-plasmalemmal densities (arrowheads), basal lamina is segmentally visible.

matrix produced and secreted by fibroblasts and myofibroblasts.

We hypothesized that these cells are mainly derived from both EECs and the bone marrow-recruited monocytes, although to our knowledge no data in the scientific literature can be found. Both of them can further differentiate into fibroblasts and contribute to the pathogenesis of fibrotic cardiac disorders [61-63]. During this process, the crosstalk between EEC and milieu is essential for tumor progression. Therefore, the existence of numerous EVs in close proximity to all cellular subtypes might be an indirect evidence for intercellular communication via EVs.

Our ultrastructural analysis showed that the activated fibroblast-like cells were found mainly in the subendothelial zone and in the outer parts of the cores, while the interior of the tumor consisted of fibrocollagenous connective tissue. Grandmougin et $a l$. in an immunohistological study of four papillary fibroelastomas found dendritic cells and cytomegalovirus (CMV) remnants, suggesting virus-induced tumor growth. These authors suggested a centrifugal 


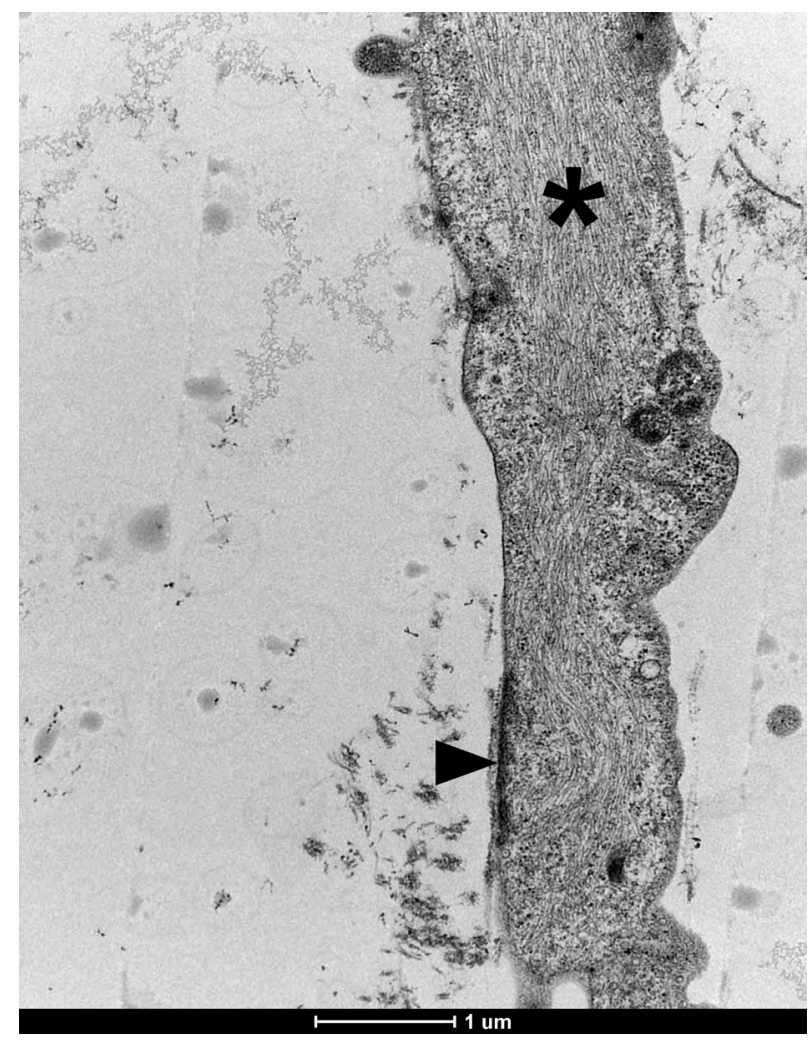

Figure 11. Higher magnification of Figure 7C, with clearly visible intermediate filaments in the cytoplasm (asterisk) and sub-plasmalemmal densities (arrowhead) in endocardial endothelial cell.

mesenchymal cell migration arising from the central layer of CPF to the superficial layer with gradual differentiation of the cells into endothelial cells [64]. Based on our observations and literature review, and contrary to Grandmougin et al. concept, we hypothesized the centripetal tumor growth of CPF.

To conclude, it may be suggested that activated EECs plays a pivotal role in the CPF formation.

\section{Acknowledgements}

We would like to express great appreciation to Adam Piecuch for his excellent immunogold staining.

\section{Funding}

This study was supported by grants from Medical University of Silesia in Katowice, Poland (grant number: KNW-1-116/N/6/I, KNW-1-065/K/7/I, KNW-1066/N/7/0, KNW-1-113/K/8/0 and KNW2B28/D/6/N).

\section{Conflict of interest}

None.

\section{Contributions}

$\mathrm{NM}$ and RW, conception and design, carried out analyses, drafting and revising the article; KK performed surgery and revising the article; NM and LM performed transmission electron microscopy sample preparation and analyses; MZ performed immunohistological and histological staining and analyses, ER-W performed immunohistological staining; NM and LM, drafting and revising the article.

\section{References}

1. Gowda RM, Khan IA, Nair CK, et al. Cardiac papillary fibroelastoma: a comprehensive analysis of 725 cases. Am Heart J. 2003; 146(3): 404-410, doi: 10.1016/S0002-8703(03)00249-7, indexed in Pubmed: 12947356.

2. Park MiY, Shin JS, Park HR, et al. Papillary fibroelastoma of the pulmonary valve. Heart Vessels. 2007; 22(4): 284-286, doi: 10.1007/s00380-006-0965-6, indexed in Pubmed: 17653525.

3. van der Meulen TA, Budde RPJ, Randjgari A, et al. Multimodality imaging of a papillary fibroelastoma of the mitral valve. Eur J Cardiothorac Surg. 2012; 42(4): 747-748, doi: 10.1093/ ejcts/ezs304, indexed in Pubmed: 22648915.

4. Sabet A, Haghighiabyaneh M, Tazelaar H, et al. The Clinical Dilemma of Cardiac Fibroelastic Papilloma. Structural Heart. 2018; 2(4): 274-280, doi: 10.1080/24748706.2018.1475782.

5. Ionescu AA, Radulescu B, Herlea V, et al. Imaging and histology in the diagnosis of multiple papillary fibroelastomas in a patient with hypertrophic obstructive cardiomyopathy. Case report. Med Ultrason. 2017; 19(4): 454-456, doi: 10.11152/ mu-1082, indexed in Pubmed: 29197925.

6. Popovic C, Yong MS, Saxena P, et al. Papillary fibroelastoma: A unique case of distant recurrence. J Thorac Cardiovasc Surg. 2019; 157(4): e125-e127, doi: 10.1016/j. jtcvs.2018.10.035, indexed in Pubmed: 30447959.

7. Malik F, Kalimuddin M, Mam K, et al. Review Article Papillary Fibroelastoma: Review Article; 2018: 2-8.

8. Darvishian F, Farmer P. Papillary fibroelastoma of the heart: report of two cases and review of the literature. Ann Clin Lab Sci. 2001; 31(3): 291-296, indexed in Pubmed: 11508834.

9. Macura O, Paleček T, Hlubocký J, et al. Papillary fibroelastoma originating from the free left ventricular wall as the cause of recurrent stroke: Description of the case and literature review. Cor et Vasa. 2016; 58(5): e466-e469, doi: 10.1016/j. crvasa.2015.09.002.

10. Taguchi E, Nakao K, Sassa T, et al. Resting angina due to papillary fibroelastoma of the right coronary cusp. Heart Vessels. 2016; 31(1): 114-117, doi: 10.1007/s00380-014-0561-0, indexed in Pubmed: 25081095.

11. Fishbein MC, Ferrans VJ, Roberts WC. Endocardial papillary elastofibromas. Histologic, histochemical, and electron microscopical findings. Arch Pathol. 1975; 99(6): 335-341, indexed in Pubmed: 1088858.

12. Sánchez-Duffhues G, García de Vinuesa A, Ten Dijke P. Endothelial-to-mesenchymal transition in cardiovascular diseases: Developmental signaling pathways gone awry. Dev Dyn. 2018; 247(3): 492-508, doi: 10.1002/dvdy.24589, indexed in Pubmed: 28891150.

13. Alvandi Z, Bischoff J. Endothelial-Mesenchymal Transition in Cardiovascular Disease. Arterioscler Thromb Vasc Biol. 2021; 41(9): 2357-2369, doi: 10.1161/ATVBAHA.121.313788, indexed in Pubmed: 34196216. 
14. Sniegon I, Prieß M, Heger J, et al. Endothelial Mesenchymal Transition in Hypoxic Microvascular Endothelial Cells and Paracrine Induction of Cardiomyocyte Apoptosis Are Mediated via TGF $\beta_{1} / \mathrm{SMAD}$ Signaling. Int J Mol Sci. 2017; 18(11), doi: 10.3390/ijms18112290, indexed in Pubmed: 29088068.

15. Liu ZH, Zhang Y, Wang X, et al. SIRT1 activation attenuates cardiac fibrosis by endothelial-to-mesenchymal transition. Biomed Pharmacother. 2019; 118: 109227, doi: 10.1016/j.biopha.2019.109227, indexed in Pubmed: 31351433.

16. Ciavarella C, Motta I, Vasuri F, et al. Involvement of miR30a-5p and miR-30d in endothelial to mesenchymal transition and early osteogenic commitment under inflammatory stress in HUVEC. Biomolecules. 2021; 11(2): 1-20, doi: 10.3390 biom11020226, indexed in Pubmed: 33562690.

17. Ranchoux B, Antigny F, Rucker-Martin C, et al. Endothelial-to-mesenchymal transition in pulmonary hypertension. Circulation. 2015; 131(11): 1006-1018, doi: 10.1161/CIRCULATIONAHA.114.008750, indexed in Pubmed: 25593290.

18. Gasparics Á, Rosivall L, Krizbai IA, et al. When the endothelium scores an own goal: endothelial cells actively augment metastatic extravasation through endothelial-mesenchymal transition. Am J Physiol Heart Circ Physiol. 2016; 310(9): H1055-H1063, doi: 10.1152/ajpheart.00042.2016, indexed in Pubmed: 26993222

19. Zhang H, Lin Y, Ma Y, et al. Protective effect of hydrogen sulfide on monocrotalineinduced pulmonary arterial hypertension via inhibition of the endothelial mesenchymal transition. Int J Mol Med. 2019; 44(6): 2091-2102, doi: 10.3892/ ijmm.2019.4359, indexed in Pubmed: 31573044.

20. Kovacic JC, Dimmeler S, Harvey RP, et al. Endothelial to mesenchymal transition in cardiovascular disease: JACC State-of-the-Art Review. J Am Coll Cardiol. 2019; 73(2): 190-209, doi: 10.1016/j.jacc.2018.09.089, indexed in Pubmed: 30654892

21. Platel V, Faure S, Corre I, et al. Endothelial-to-Mesenchymal Transition (EndoMT): roles in tumorigenesis, metastatic extravasation and therapy resistance. J Oncol. 2019; 2019: 1-13, doi: 10.1155/2019/8361945, indexed in Pubmed: 31467544.

22. Kaczmarek K, Jakubowski P, Wojnicz R, et al. A local cryotherapy with percutaneous tumour removal as a successful treatment option in patient with tricuspid valve fibroelastoma papillare. Eur Heart J. 2016; 38(18): ehw516, doi: 10.1093/ eurheartj/ehw516, indexed in Pubmed: 27941010.

23. Cecoltan S, Ciortan L, Macarie R, et al. High glucose induced changes in human VEC phenotype in a 3D hydrogel derived from cell-free native aortic root. Front Cardiovasc Med. 2021; 8: 1-13, doi: 10.3389/fcvm.2021.714573, indexed in Pubmed: 34458339.

24. van Niel G, D'Angelo G, Raposo G. Shedding light on the cell biology of extracellular vesicles. Nat Rev Mol Cell Biol. 2018; 19(4): 213-228, doi: 10.1038/nrm.2017.125, indexed in Pubmed: 29339798.

25. Díaz-Flores L, Gutiérrez R, Alvarez-Argüelles H, et al. Extracellular multivesicular bodies in tissues affected by inflammation/repair and tumors. Ultrastruct Pathol. 2018; 42(5): 448-457, doi: 10.1080/01913123.2018.1534915, indexed in Pubmed: 30383502

26. Kalra H, Drummen GPC, Mathivanan S. Focus on Extracellular Vesicles: Introducing the Next Small Big Thing. Int J Mol Sci. 2016; 17(2): 170, doi: 10.3390/ijms17020170, indexed in Pubmed: 26861301.

27. Fu S, Zhang Y, Li Y, et al. Extracellular vesicles in cardiovascular diseases. Cell Death Discovery. 2020; 6(1), doi: 10.1038/ s41420-020-00305-y, indexed in Pubmed: 32821437.
28. Loyer X, Vion AC, Tedgui A, et al. Microvesicles as cell-cell messengers in cardiovascular diseases. Circ Res. 2014; 114(2): 345-353, doi: 10.1161/CIRCRESAHA.113.300858, indexed in Pubmed: 24436430.

29. Mathiesen A, Hamilton T, Carter N, et al. Endothelial extracellular vesicles: from keepers of health to messengers of disease. Int J Mol Sci. 2021; 22(9), doi: 10.3390/ijms22094640, indexed in Pubmed: 33924982.

30. Ci HB, Ou ZJ, Chang FJ, et al. Endothelial microparticles increase in mitral valve disease and impair mitral valve endothelial function. Am J Physiol Endocrinol Metab. 2013; 304(7): E695-E702, doi: 10.1152/ajpendo.00016.2013, indexed in Pubmed: 23384770.

31. Lin ZB, Ci HB, Li Y, et al. Endothelial microparticles are increased in congenital heart diseases and contribute to endothelial dysfunction. J Transl Med. 2017; 15(1): 4, doi: 10.1186/s12967-016-1087-2, indexed in Pubmed: 28049487.

32. $\mathrm{Fu} \mathrm{Li}, \mathrm{Hu} \mathrm{XX}, \mathrm{Lin} \mathrm{ZB}$, et al. Circulating microparticles from patients with valvular heart disease and cardiac surgery inhibit endothelium-dependent vasodilation. J Thorac Cardiovasc Surg. 2015; 150(3): 666-672, doi: 10.1016/j.jtcvs.2015.05.069, indexed in Pubmed: 26145768.

33. Hromada C, Mühleder S, Grillari J, et al. Endothelial extracellular vesicles-promises and challenges. Front Physiol. 2017; 8: 275, doi: 10.3389/fphys.2017.00275, indexed in Pubmed: 28529488 .

34. Fujimoto S, Fujita Yu, Kadota T, et al. Intercellular communication by vascular endothelial cell-derived extracellular vesicles and their MicroRNAs in respiratory diseases. Front Mol Biosci. 2021; 7: 1-14, doi: 10.3389/fmolb.2020.619697, indexed in Pubmed: 33614707.

35. Yeon JuH, Jeong HE, Seo H, et al. Cancer-derived exosomes trigger endothelial to mesenchymal transition followed by the induction of cancer-associated fibroblasts. Acta Biomater. 2018; 76: 146-153, doi: 10.1016/j.actbio.2018.07.001, indexed in Pubmed: 30078422.

36. Haynes BA, Yang LiF, Huyck RW, et al. Endothelial-to-mesenchymal transition in human adipose tissue vasculature alters the particulate secretome and induces endothelial dysfunction. Arterioscler Thromb Vasc Biol. 2019; 39(10): 2168-2191, doi: 10.1161/ATVBAHA.119.312826, indexed in Pubmed: 31434495.

37. Akbar N, Digby JE, Cahill TJ, et al. Oxford Acute Myocardial Infarction (OxAMI) Study. Endothelium-derived extracellular vesicles promote splenic monocyte mobilization in myocardial infarction. JCI Insight. 2017; 2(17), doi: 10.1172/ jci.insight.93344, indexed in Pubmed: 28878126.

38. Nikolova-Krstevski V, Leimena C, Fatkin D. Mechanical stretch alters the morphology and function of atrial endocardial endothelial cells. Hear lung circ [Internet]. 2012; 21(1):S61. Available from: http://journals. sagepub.com/doi/10.1177/021849239400200118, doi: 10.1177/021849239400200118.

39. Dal-Bianco JP, Aikawa E, Bischoff J, et al. Active adaptation of the tethered mitral valve: insights into a compensatory mechanism for functional mitral regurgitation. Circulation. 2009; 120(4): 334-342, doi: 10.1161/CIRCULATIONAHA.108.846782, indexed in Pubmed: 19597052.

40. Cho J, Lee A, Chang W, et al. Endothelial to Mesenchymal Transition Represents a Key Link in the Interaction between Inflammation and Endothelial Dysfunction. Front Immunol. 2018; 9, doi: 10.3389/fimmu.2018.00294, indexed in Pubmed: 29515588 . 
41. Li Y, Lui KO, Zhou B. Reassessing endothelial-to-mesenchymal transition in cardiovascular diseases. Nat Rev Cardiol. 2018; 15(8): 445-456, doi: 10.1038/s41569-018-0023-y, indexed in Pubmed: 29748594.

42. Bischoff J, Aikawa E. Progenitor cells confer plasticity to cardiac valve endothelium. J Cardiovasc Transl Res. 2011; 4(6): 710-719, doi: 10.1007/s12265-011-9312-0, indexed in Pubmed: 21789724.

43. Bischoff J. Endothelial-to-Mesenchymal Transition. Circ Res. 2019; 124(8): 1163-1165, doi: 10.1161/CIRCRESAHA.119.314813, indexed in Pubmed: 30973806.

44. Haack T, Abdelilah-Seyfried S. The force within: endocardial development, mechanotransduction and signalling during cardiac morphogenesis. Development. 2016; 143(3): 373-386, doi: 10.1242/dev.131425, indexed in Pubmed: 26839341.

45. Zhang H, Lui KO, Zhou B. Endocardial Cell Plasticity in Cardiac Development, Diseases and Regeneration. Circ Res. 2018; 122(5): 774-789, doi: 10.1161/CIRCRESAHA.117.312136, indexed in Pubmed: 29496799.

46. Piera-Velazquez S, Jimenez SA. Molecular mechanisms of endothelial to mesenchymal cell transition (EndoMT) in experimentally induced fibrotic diseases. Fibrogenesis Tissue Repair. 2012; 5(Suppl 1): S7, doi: 10.1186/1755-1536-5-S1-S7, indexed in Pubmed: 23259736.

47. Islam S, Boström KI, Di Carlo D, et al. The mechanobiology of endothelial-to-mesenchymal transition in cardiovascular disease. Front Physiol. 2021; 12: 734215, doi: 10.3389/ fphys.2021.734215, indexed in Pubmed: 34566697.

48. Levine R, Hagége A, Judge D, et al. Mitral valve disease-morphology and mechanisms. Nat Rev Cardiol. 2015; 12(12): 689-710, doi: 10.1038/nrcardio.2015.161, indexed in Pubmed: 26483167.

49. Welch-Reardon KM, Wu N, Hughes CCW. A role for partial endothelial-mesenchymal transitions in angiogenesis? Arterioscler Thromb Vasc Biol. 2015; 35(2): 303-308, doi: 10.1161/ ATVBAHA.114.303220, indexed in Pubmed: 25425619.

50. Paruchuri S, Yang JH, Aikawa E, et al. Human pulmonary valve progenitor cells exhibit endothelial/mesenchymal plasticity in response to vascular endothelial growth factor-A and transforming growth factor-beta2. Circ Res. 2006; 99(8): 861-869, doi: 10.1161/01.RES.0000245188.41002.2c, indexed in Pubmed: 16973908.

51. Zhong A, Mirzaei Z, Simmons CA. The roles of matrix stiffness and $B$-catenin signaling in endothelial-to-mesenchymal transition of aortic valve endothelial cells. Cardiovasc Eng Technol. 2018; 9(2): 158-167, doi: 10.1007/s13239-018-03630, indexed in Pubmed: 29761409.

52. Cieslik KA, Trial J, Crawford JR, et al. Adverse fibrosis in the aging heart depends on signaling between myeloid and mesenchymal cells; role of inflammatory fibroblasts. J Mol Cell
Cardiol. 2014; 70: 56-63, doi: 10.1016/j.yjmcc.2013.10.017, indexed in Pubmed: 24184998.

53. Bucala R. Review series-inflammation \& fibrosis. Fibrocytes and fibrosis. QJM. 2012; 105(6): 505-508, doi: 10.1093/qjmed/ hcs068, indexed in Pubmed: 22627257.

54. Geiger A, Walker A, Nissen E. Human fibrocyte-derived exosomes accelerate wound healing in genetically diabetic mice. Biochem Biophys Res Commun. 2015; 467(2): 303309, doi: 10.1016/j.bbrc.2015.09.166, indexed in Pubmed: 26454169.

55. Suda S, Williams H, Medbury HJ, et al. A review of monocytes and monocyte-derived cells in hypertrophic scarring post burn. J Burn Care Res. 2016; 37(5): 265-272, doi: 10.1097/ BCR.0000000000000312, indexed in Pubmed: 27003739.

56. Alex L, Frangogiannis NG. The cellular origin of activated fibroblasts in the infarcted and remodeling myocardium. Circ Res. 2018; 122(4): 540-542, doi: 10.1161/CIRCRESAHA.118.312654, indexed in Pubmed: 29449358.

57. Meng XM, Wang S, Huang XR, et al. Inflammatory macrophages can transdifferentiate into myofibroblasts during renal fibrosis. Cell Death Dis. 2016; 7(12): e2495, doi: 10.1038/ cddis.2016.402, indexed in Pubmed: 27906172.

58. Liu D, Yan W, Huang J, et al. Macrophages in ischemic heart failure: yesterday, today, and tomorrow. Cardiol Discov. 2021; 1(2): 128-134, doi: 10.1097/cd9.0000000000000010.

59. Moskalik A, Niderla-Bielińska J, Ratajska A. Multiple roles of cardiac macrophages in heart homeostasis and failure. Heart Fail Rev. 2021 [Epub ahead of print], doi: 10.1007/s10741021-10156-z, indexed in Pubmed: 34387811.

60. Haider N, Boscá L, Zandbergen HR, et al. Transition of macrophages to fibroblast-like cells in healing myocardial infarction. J Am Coll Cardiol. 2019; 74(25): 3124-3135, doi: 10.1016/j.jacc.2019.10.036, indexed in Pubmed: 31856969.

61. Keeley EC, Mehrad B, Strieter RM. The role of circulating mesenchymal progenitor cells (fibrocytes) in the pathogenesis of fibrotic disorders. Thromb Haemost. 2009; 101(4): 613-618, indexed in Pubmed: 19350102.

62. Lin RJ, Su ZZ, Liang SM, et al. Role of circulating fibrocytes in cardiac fibrosis. Chin Med J (Engl). 2016; 129(3): 326-331, doi: 10.4103/0366-6999.174503, indexed in Pubmed: 26831236.

63. Rios FJ, Harvey A, Lopes RA, et al. Progenitor cells, bone marrow-derived fibrocytes and endothelial-to-mesenchymal transition: new players in vascular fibrosis. Hypertension. 2016; 67(2): 272-274, doi: 10.1161/HYPERTENSIONAHA.115.06220, indexed in Pubmed: 26693817.

64. Grandmougin D, Fayad G, Moukassa D, Decoene C, Abolmaali K, Bodart JC, et al. Cardiac valve papillary fibroelastomas: clinical, histological and immunohistochemical studies and a physiopathogenic hypothesis. J Heart Valve Dis [Internet]. 2000 Nov; 9(6):832-841, indexed in Pubmed: 11128794.

Submitted: 28 May, 2021

Accepted after reviews: 30 November, 2021

Available as AoP: 8 December, 2021 